The University of Southern Mississippi The Aquila Digital Community

Faculty Publications

4-1-1998

\title{
Authority and Sexuality in Early Modern Burgundy $(1550-1730)$
}

Kathryn A. Edwards

University of Southern Mississippi

Follow this and additional works at: http://aquila.usm.edu/fac_pubs

Part of the History Commons

\section{Recommended Citation}

Edwards, K. A. (1998). Authority and Sexuality in Early Modern Burgundy (1550-1730). Renaissance Quarterly, 51(1), 259-260. Available at: http://aquila.usm.edu/fac_pubs/4955

This Book Review is brought to you for free and open access by The Aquila Digital Community. It has been accepted for inclusion in Faculty Publications by an authorized administrator of The Aquila Digital Community. For more information, please contact Joshua.Cromwell@usm.edu. 
Antoine, with whom he lives, divorces Anne Le Fert in 1557. Calvin's unsavory role in his brother's marital tensions and eventual divorce vividly illustrates the effects a troubled couple could have on those regularly interacting with them.

Kingdon's work complements his own broader studies of Geneva as well as those made by E. William Monter and William Naphy, and his has a wider application than the title may suggest. Through his analyses of marriage and punishment he puts Geneva back into the debates over the Reformation's social impact and confessionalization. When combined with his lucidity and storytelling ability, these qualities make this book a superb source for both classroom instruction and the Reformation specialist.

KATHRYN A. EDWARDS

University of Southern Mississippi

James R. Farr. Authority and Sexuality in Early Modern Burgundy (1550-1730). New York and Oxford: Oxford University Press, 1995. 252 pp. \$45. ISBN: 0-19-5089073.

James Farr is one of the leading authorities in the United States on early modern Burgundy, a status which he has achieved in part through years of careful research in that province's departmental and municipal archives. Based on judicial records from throughout that region, this work builds on his previous studies of Dijon's artisans, political morality, and social and cultural change during the Reformation.

Despite early Protestant challenges, Burgundy remained intensely Catholic, supporting the League long after the Guises had yielded. Burgundy's parlement and town councils orchestrated this conservative response, a subject that Mack Holt is currently studying. Concerned with the cultural and intellectual effects of these struggles and this choice, Farr uses the Burgundian discourse about and treatment of the human body as a means of assessing the Reformation's impact on ideology and its representations. Building on recent work by Caroline Walker Bynum, Judith Butler, and many others whom he acknowledges, he regards the body as a "field of struggle," a Foucauldian site on which culture inscribes its values (6). In order to assess the relationships among law, religion, and sexual morality, Farr divides his work into two sections. The first half discusses the development of sexual ideologies. Rather than settling for the prescriptions of parlementaires and clergy, Farr attempts to assess the standards taught to "ordinary" people. Although these beliefs are difficult to access, his description of common ideas, the ways they could be transmitted, and the mutations they suffered is quite convincing. In the process, he describes the growing ideal of a "sacralized society [that] would criminalize sin." This "new moral order could be established only if people embraced self-discipline and submitted to systems of social control" (58). The second half of this work analyzes the means by 
which self-discipline and social control were enforced. Here human sexuality and the body repeatedly figure as sites of struggle. Clerical sexual misconduct, bride theft $(r e f t)$, infanticide, lasciviousness, and prostitution are among the crimes that Farr considers in light of their social implications and cultural innovations. He also stresses (in certain fields) the difficulties involved in assessing the degree of change: "we can never be certain whether these changes were in fact occurring or were simply reflecting a shift in prosecution patterns or intensity" (150). Even with that caveat, he successfully traces a transition in the Burgundian order based on the relationship among the law, holiness, sexuality, and power.

In his introduction, Farr states: “This book is less about the 'success' or 'failure' of the Catholic Reformation in Burgundy than the dialectical dynamics of the formulation of the new order, its attempted imposition, and the uses of the law that was so central to it" (9). This work not only lives up to its stated purposes but, in so doing, shows a great depth of learning and unwillingness to settle for simplistic assessments. It should serve as an interpretive model and research guide to scholars interested in social history, the Counter Reformation, sexuality, and gender.

KATHRYN A. EDWARDS

University of Southern Mississippi

Peter Auski. Christian Plain Style: The Evolution of a Spiritual Ideal. Montreal and Kingston: McGill-Queen's University Press, 1995. xii +371 pp. \$49.95. ISBN: 0-7735-1220-9.

Jelle Koopmans, Mark A. Meadow, Kees Meerhoff, and Marijke Spies, eds. Rhetoric-Rhétoriqueurs-Rederijkers. Amsterdam, Oxford, New York, and Tokyo: North Holland, 1995. vi +282 pp. Dfl.85. ISBN: 0-444-85792-3.

Peter Auski's project of writing a history of the concept of a plain style in classical rhetoric, as it was taken up and reapplied in the Christian tradition, was certainly justified, although he may not have realized the sheer amount of material with which he would have to deal. In effect, he attempts a parallel history of both classical and Christian traditions, stopping at the end of the seventeenth century, but with an epilogue recording them both still flourishing in John Wesley's Directions concerning Pronunciation and Gesture (1727). Apart from the misnomer in his title - he discovers no "evolution," only a constant recurrence of the same terms and categories in different periods and cultures - his book can be recommended as a pertinacious survey of a huge range of material.

Definitions of plainness, he shows in the introduction, are variable and often couched in terms of negation, plainness or simplicity being the absence of ornament or display. (Rather like the word "peace," which dictionaries define as freedom from war, as if it had no natural identity in itself.) In 